Respiration 2016;91:349

DOI: $10.1159 / 000444883$

\section{Is a Heated Breathing Tube the Emergent Factor for Continuous Positive Airway Pressure Therapy in Obstructive Sleep Apnea?}

\author{
Cristiana Cruz $^{a}$ Pedro Santos ${ }^{a}$ Antonio M. Esquinas ${ }^{b}$ \\ a Pulmonology Unit, Centro Hospitalar e Universitário de \\ Coimbra, Hospitais da Universidade de Coimbra, Coimbra, \\ Portugal; ' Intensive Care Unit, Hospital Morales Meseguer, \\ Murcia, Spain
}

We carefully read the article by Galetke et al. [1] where the use of a heated breathing tube versus a conventional heated humidifier during the use of continuous positive airway pressure (CPAP) was evaluated. Like in other studies, the authors concluded that the quality of sleep and respiratory disturbances was improved by both treatments [2-4] and with no difference between them. However, we suggest that there are some key aspects to consider.

First, with respect to side effects, it is known that the use of CPAP causes a dry nose, mouth and throat, which can be minimized by using a heated humidifier $[2,3,5]$. In this trial, the patients were not divided into subgroups according to comorbidities. Furthermore, the authors did not measure the room temperature and did not analyze the side effects by season. These analyses should demonstrate if there are differences between seasons or if the heated breathing tube is more effective at low temperatures. There are some factors that predict the need for additional humidification during CPAP, including chronic disease of the nasal mucosa or previous nasal operations, which would be interesting to know in this study [5].

Second, the authors observed that the adherence to the treatment of patients who used the heated breathing tube was $1 \mathrm{~h}$ longer than in the other group; this is an important point that deserves more attention and probably another trial.

Despite this, more studies, including an analysis of subgroups, are needed to provide more information about which patients can benefit from this treatment.

\section{References}

1 Galetke W, Nothofer E, Priegnitz C, Anduleit N, Randerath W: Effect of a heated breathing tube on efficacy, adherence and side effects during continuous positive airway pressure therapy in obstructive sleep apnea. Respiration 2016;91:18-25.

-2 Massie CA, Hart RW, Peralez K, Richards GN: Effects of humidification on nasal symptoms and compliance in sleep apnea patients using continuous positive airway pressure. Chest 1999;116:403-408.

3 Neill AM, Wai HS, Bannan SP, Beasley CR, Weatherall M, Campbell AJ: Humidified nasal continuous positive airway pressure in obstructive sleep apnoea. Eur Respir J 2003;22:258-262.

4 Nilius G, Domanski U, Franke KJ, Ruhle KH: Impact of a controlled heated breathing tube humidifier on sleep quality during CPAP therapy in a cool sleeping environment. Eur Respir J 2008;31:830-836.

5 Rakotonanahary D, Pelletier-Fleury N, Gagnadoux F, Fleury B: Predictive factors for the need for additional humidification during nasal continuous positive airway pressure therapy. Chest 2001;119:460-465.

\section{KARGER}

E-Mail karger@karger.com www.karger.com/res
() 2016 S. Karger AG, Base

0025-7931/16/0914-0349\$39.50/0
Cristiana Cruz, MD

Pulmonology Unit, Centro Hospitalar e Universitário de Coimbra Hospitais da Universidade de Coimbra, Praceta Prof. Mota Pinto PT-3000-075 Coimbra (Portugal)

E-Mail cristiana.rl.cruz@gmail.com 